\title{
Art for a New Monarchy: Aragon in the Late Eleventh Century ${ }^{1}$
}

\author{
David L. SIMON \\ Colby College
}

This paper has as its focus the relationship between the Aragonese monarchy and art of the end of the eleventh century and the beginning of the twelfth century that defined it, that is, Aragonese art that is coeval with the reign of Alfonso VI in Castile and Leon. Although Alfonso VI's territories were nearly adjacent to those of the kingdom of Aragon, the historical situation of the two kingdoms was very different indeed. As opposed to Castile and Leon, ancient kingdoms that could claim a long monarchic tradition, Aragon was founded as a kingdom only in the eleventh century by Ramiro I, who, in fact, might well be considered to have defied the legitimate authority of García de Nájera, the rightful heir of their father, Sancho III el Mayor, deceased in $1035 .^{2}$ In the felicitous words of Antonio Ubieto Arteta: "En realidad, Ramiro I es un rey de hecho no de derecho." ${ }^{3}$ During the reigns of Ramiro I's heirs, above all that of Sancho Ramírez, the authority of the Aragonese monarchy was greatly strengthened and at the same time a royal building program was undertaken, which, in large measure, relied on a number of antique precedents, as such recalling a putative historic past that in reality never existed. Despite the forcefulness with which Sancho Ramírez established his kingdom, various threats challenged the capacity of Aragonese monarchs to maintain the integrity of their territories and checked their attempts to expand them. Some of these threats were

1 I am particularly grateful to Prof. Javier Martínez de Aguirre and the organizers of «Alfonso VI y el arte de su época» at the Universidad Complutense de Madrid for their invitation to read a paper in that conference, which served as the basis for this article. I would also like to acknowledge support for my investigations on Jaca cathedral from the Program for Cultural Cooperation between Spain's Ministry of Culture and United States Universities. Sonia C. Simon's careful reading of my text and her many suggestions are as much appreciated as they were crucial. Photographs from Antonio García Omedes and David L. Simon, Jr. are acknowledged with gratitude. This study is part of a larger project, "Arte y monarquía en el nacimiento y consolidación del reino de Aragón", for which Prof. Martínez de Aguirre serves as principal investigator and which has been funded by the Ministerio de Ciencia e Innovación of the Government of Spain.

2 A. Ubieto Arteta, "Ramiro I de Aragón y su concepto de la realeza," Cuadernos de historia de España, XX (1953), pp. 45-64; A. UBieto ARTETA, Historia de Aragón: Creación y desarrollo de la Corona de Aragón, Zaragoza, 1987. For a differing view, see A. DuRán GudioL, Ramiro I de Aragón, Zaragoza, 1978, pp. 19-36. Durán Gudiol recognizes, nonetheless, that as early as the beginning of the twelfth century questions were raised about the legitimacy of Ramiro's birth.

A. Ubieto Arteta, "Ramiro I de Aragón y su concepto de la realeza," Cuadernos de historia de España, XX (1953), p. 60. 
from Aragon's Muslim neighbors to the south, but others were probably a result of the historical circumstances of Ramiro I's assumption or usurpation of kingship, which, in part at least, were used in the 1080's to justify the attempts by Alfonso VI of Castile to annex Zaragoza. ${ }^{4}$ In the same decade Sancho Ramírez's brother García, Bishop of Jaca, was accused of treachery, precisely for supporting Alfonso VI. ${ }^{5}$ This paper concentrates on the monarchical monument par excellence of the late-eleventh-century kingdom of Aragon, the cathedral of Jaca, where the expressive content of its architecture and decoration can be related to the monarchic ambitions of its royal patrons. One must acknowledge that Jaca's sway diminished significantly after the nearby city of Huesca was captured from its Muslim occupiers in 1096, when royal energies were redirected in order to develop a royal platform for that newly conquered city. But, during the late eleventh century, royal aspirations were made manifest predominantly in Jaca and the Jacetania.

Jaca's situation today as a refreshingly tranquil, relatively remote, and still small Pyrenean city, relying for its wellbeing on its role as both a winter and summer resort, belies its historical importance during the late eleventh and early twelfth centuries, when the capital of the kingdom of Aragon and its episcopal see were established there. Many generations of scholars, including those who were among the first to study Romanesque art, have been uniform in their appreciation of the significance of Jaca cathedral, not only for the development of Iberian Romanesque art but also for that of much of Western Europe. ${ }^{6}$ In many ways, and as result of its location, Jaca was a crossroads: ${ }^{7}$ when Aragon absorbed the territories of Sobrarbe and Ribagorza, around $1044,{ }^{8}$ Jaca came to dominate the political space between the powerful county of Cataluña and the kingdom of Navarra. Jaca was also adjacent to the French lands of Gascony, located only some twenty-five kilometers away via the Somport Pass, on one of the major routes that pilgrims took on their journey to Santiago de Compostela. ${ }^{9}$ Somport is mentioned in the famous twelfth century pilgrim's guide, as

4 A. Durán Gudiol, Ramiro I de Aragón, Zaragoza, 1978, pp. 27-28; B. ReILly, The Kingdom of LeónCastilla under King Alphonso VI, 1065-1109, Princeton, 1988, pp. 68-92; D. J. Buesa Conde, Sancho Ramírez, Rey de Aragoneses y Pamploneses (1064-1084), Zaragoza, 1996, pp. 110-112; 164-169.

5 P. Kenr, Cómo y cuándo se hizo Aragón feudatario de la Santa Sede, Zaragoza, 1945, pp. 285-326; A. Durán Gudiol, La Iglesia de Aragón durante los reinados de Sancho Ramírez y Pedro I (1062?-1104), Rome, 1962, pp. 44-51; A. Durán Gudiol, Ramiro I de Aragón, Zaragoza, 1978, p. 28; D. J. Buesa Conde, "Catedral de Jaca", Las catedrales de Aragón, Zaragoza, 1987, pp. 58; D. J. Buesa Conde, Sancho Ramírez, Rey de Aragoneses y Pamploneses (1064-1084), Zaragoza, 1996, pp. 156-169.

6 A.K. Porter, "The Tomb of Doña Sancha and the Romanesque Art of Aragon", Burlington Magazine 45 (1924), pp. 165-179; ID., Spanish Romanesque Sculpture I, New York 1928; M. Gómez Moreno, El arte románico español, Madrid, 1934; G. GaIllard, Les débuts de la sculpture romane espagnole: León, Jaca, Compostelle, Paris 1938.

7 T. N. Bisson, The Medieval Crown of Aragon. A Short History, Oxford, 1986, p. 13.

8 A. Durán Gudiol, Ramiro I de Aragón, Zaragoza, 1978, pp. 49-54.

9 D.J. Buesa Conde, "Los caminos de Santiago. Aragón, Somport y Jaca”, Los caminos de Santiago. Arte, Historia, Literatura, Zaragoza, 2005, pp. 7-28. 
is Jaca, described as one of the first Spanish destinations for pilgrims crossing the frontier. ${ }^{10}$

Four overriding issues have dominated scholarship on the early Romanesque art of the kingdom of Aragon and the cathedral of Jaca has been central to each of them. The first is the chronology of the cathedral and its decorative program, debated, often with vehemence, for more than half a century, a debate that has focused on historical facts and interpretations of documents as much as on artistic production. The second relates to the sources and careers of Jaca's sculptors and questions stylistic affinities between Jaca and other works, Iberian as well as ultraPyrenean. The third issue concerns the interpretation of the meaning of many of the Romanesque sculptures of the cathedral, some of which remain undeciphered. And the fourth, the question of what the original Romanesque cathedral of Jaca looked like, will be central to this study.

A traditional chronology for Jaca cathedral relied on documents, putatively dated to 1063 that recorded the establishment of a bishopric in Jaca, made necessary because the former episcopal see, Huesca, was in Muslim hands. These documents, which describe in unusual detail a completed cathedral in Jaca, we now know, thanks to studies by Antonio Ubieto Arteta and Antonio Durán Gudiol, to be later falsifications. ${ }^{11}$ A revised chronology dates the establishment of a cathedral to the next decade, since only in the 1070's would there have been the occasion and the necessity to build a cathedral there. Jaca was not recognized as a city, a civitas, until the 1070's and, as Ubieto demonstrates, only a city could house a bishopric. ${ }^{12}$ It was only after 1077 that the Bishop of Aragon is consistently cited as Bishop of Jaca; he was, in fact, Garcia, prince of Aragon and brother of King Sancho Ramírez. ${ }^{13}$ Jaca's growth as a city, apparently rapid, was encouraged around this time, in 1076 or 1077, by Sancho Ramírez's concession to Jaca of fueros, among the first civic charters of a type that would later become widespread in Christian Iberia. ${ }^{14}$

10 W. Melczer, The Pilgrim's Guide to Compostela, New York, 1993, p. 86; P. Gerson, A. ShaverCrandell, A. Stones, and J. Krochalis, The Pilgrim's Guide: A Critical Edition, II, London, 1998, pp. 14-15.

11 A. Ubieto Arteta, «La catedral románica de Jaca: problemas de cronología», Pirineos, 17-18 (19611962), pp. 125-137; A. DurÁn Gudiol, La iglesia de Aragón durante los reinados de Sancho Ramírez y Pedro I, Roma, 1962, pp. 137-140; A. Ubieto ARTETA, «El románico de la catedral jaquesa y su cronología”, Príncipe de Viana, 25 (1964), pp. 187-200; D. J. Buesa Conde, "Actas del Concilio de Jaca”, El espejo de nuestra historia. La diócesis de Zaragoza a través de los siglos, Zaragoza, 1991, pp. 170-172.

12 A. Ubieto Arteta, Historia de Aragón: Divisiones administrativas, Zaragoza, 1983, pp. 21-22.

13 A. Durán Gudiol, La iglesia de Aragón durante los reinados de Sancho Ramírez y Pedro I, Roma, 1962, 37-51; 105; D. J. BuEsA Conde, El rey Sancho Ramírez, Zaragoza, 1978, pp. 55-57.

14 J. M. Lacarra, "Desarrollo urbano de Jaca en la Edad Media", Estudios de Edad Media de la Corona de Aragón, IV (1951), pp. 139-155; L. H. Nelson, "The Foundation of Jaca (1076): Urban Growth in Early Aragon", Speculum, 53 (1978), pp. 688-708; M. I. FAlcón PÉrez, "Una ciudad de franquicia: Jaca”, Sancho Ramírez, rey de Aragón, y su tiempo. 1064-1094, Huesca, 1994, pp. 114-120; M. I. FALCón PÉRez, "Trayetoria medieval de Jaca en el seno de la Corona de Aragón", Actas del XV Congreso de Historia de la Corona de Aragón, III, Zaragoza, 1994, pp. 13-22. 
Moreover, a revised chronology that would see Jaca cathedral begun in the late 1070's corresponds, in general terms at least, with that of the monuments to which Jaca would seem to be most closely related on the basis of style, monuments that, like Jaca, are located on the pilgrimage road to Santiago de Compostela and whose construction began in the 1070's or early 1080's and continued through the first few decades of the twelfth century: San Sernin in Toulouse, San Martín in Frómista, San Isidoro in Leon, and the cathedral of Santiago itself. ${ }^{15}$

Despite the logic of the arguments for dating much of Jaca's construction to the last third of the eleventh century and the first third of the following one, ${ }^{16}$ studies by Juan Francisco Esteban Lorente suggest that construction began much earlier in the eleventh century than had ever been suggested previously, perhaps as early as the second or third decade of the century, and that it continued, albeit with programmatic and formal changes, for at least a century. ${ }^{17}$ The sculpture, ample, varied, and of high quality, that decorates the cathedral, would thus, by my reading of the situation, reflect changes in program. Indeed, the programmatic changes were multiple and probably were not only a result of the change in building practice, since a number of interior capitals contain separate blocks of stone that were added to the tops of the capitals, reflecting perhaps an enlargement of the building that required larger capitals than were originally called for. ${ }^{18}$ The apparently conflicting evidence offered by Esteban and previous research can probably be reconciled by recalling that much of the dating, previous to Esteban, was based on comparison between the sculpture of the cathedral and that of other monuments, not by a study of its architectural program. The initial program, in

15 M. Gómez Moreno, El arte románico español, Madrid, 1934; G. GaIllard, Les débuts de la sculpture romane espagnole: León, Jaca, Compostelle, Paris, 1938; T. Lyman, "Notes on the Miégeville Capitals and the Construction of Saint-Sernin in Toulouse", The Art Bulletin, XLIX (1967), p. 28; T. Lyman, "The Pilgrimage Roads Revisited," Gesta, VIII (1969), p. 41; S. Moralejo Álvarez, "Un sculpture du style de Bernard Gilduin à Jaca," Bulletin monumental, CXXXI (1973), pp. 7-16; S. Moralejo Álvarez, "La lauda sepulcral de Alfonso Ansúrez (+ 1093): su lugar en el desarrollo de la escultura románica hispánica y sus relaciones con el arte jaqués," Primer coloquio de Arte Aragonés. Textos de las comunicaciones y ponencias, Teruel, 1978, pp. 197-218; S. Moralejo Álvarez, "La sculpture romane de la Cathédrale de Jaca. Etat des questions", Les Cahiers de Saint-Michel de Cuxa, 10 (1979), pp. 81-85; M. DuRLIAT, La sculpture romane de la route de Saint-Jacques: De Conques à Compostelle, Mont-de-Marsan, 1990.

16 S. Moralejo Állvarez, "Un sculpture du style de Bernard Gilduin à Jaca," Bulletin monumental, CXXXI (1973), pp. 7-16; S. Moralejo Álvvarez, "La sculpture romane de la Cathédrale de Jaca. Etat des questions", Les Cahiers de Saint-Michel de Cuxa, 10 (1979), pp. 79-85.

17 J. F. Esteban Lorente, "La metrología de la catedral románica de Jaca: 1", Artigrama, XIV (1999), pp. 241-262; J. F. Esteban Lorente, "La metrología de la catedral románica de Jaca: 2", Artigrama, XV (2000), pp. 231-258; J. F. Esteban LoREnTE, "La metrología y sus consecuencias en las iglesias de la Alta Edad Media española. IV. El románico del último tercio del siglo XI", Artigrama, XXIII (2008), pp. 387-396. See as well B. Cabañero Subiza, "Precedentes musulmanes y primer arte cristiano", Las Cinco Villas aragonesas en la Europa de los siglos XI y XII: de la frontera natural a las fronteras politicas y socioeconómicas (foralidad y muncipalidad), Zaragoza, 2005, pp. 207-248.

${ }_{18}$ D. L. Simon, "San Adrián de Sasave and Sculpture in Altoaragón", Romanesque and Gothic: Essays for George Zarnecki, London, 1987, pp. 179-184. 
keeping with Aragonese building methods of the early eleventh century, undoubtedly did not include elaborate sculpture, if any sculpture at all. One wonders if it was the change in the status of Jaca, its designation as a city and as episcopal see, which served as the impetus for the constructional and programmatic changes to the building. If so, what I refer to above as the revised chronology would reflect and correspond to historical and cultural changes in Jaca. It is significant that the monuments mentioned above with stylistic affinities to Jaca, and there are others that could be cited equally well, are outside Aragon, that is, that the architecture and sculpture of the cathedral comes to represent a "new" architectural and decorative paradigm for the kingdom.

Thus, the cathedral of Jaca is probably the product of a much slower development than it would at first appear, since its most prominent constructive features are those that reject the traditional manner of building in Altoaragón, that is precisely those features that must have characterized the cathedral's original building program, which Esteban describes. The point can best be illustrated by comparing Jaca cathedral (fig.1) with the Torre de la Reina within the castle confines of Loarre (fig. 2 ), of about 1020 or 1030 , or with the church of San Caprasio in Santa Cruz de la Serós (fig. 3), of about the same date, ${ }^{19}$ buildings in the socalled First Romanesque or Lombard style. Evident is the change from the irregular masonry (sillarejo) of the early buildings to the evenly cut and finely laid ashlar masonry (silleria) of the cathedral. Apparent as well at Jaca and absent in the early works of the region are decorative features such as billet moldings, which articulate and separate

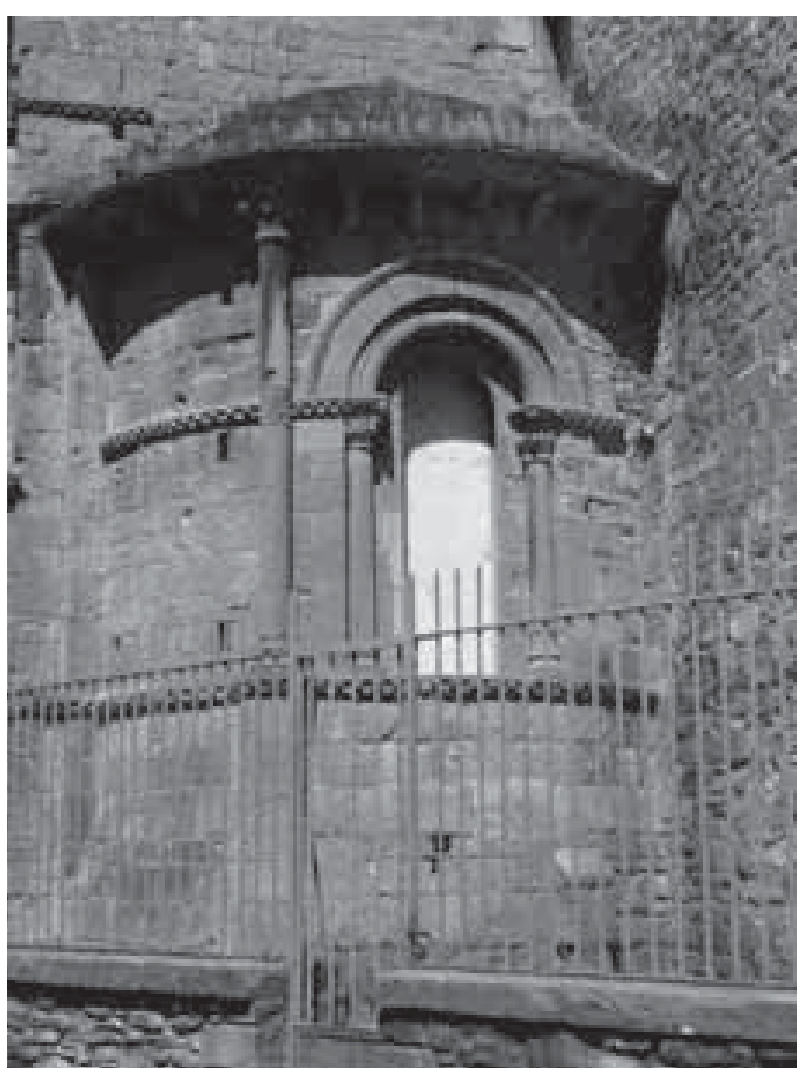

Fig. 1. South apse, Jaca cathedral. Foto: D. L. Simon, Jr.

19 J. F. Esteban Lorente, F. Galtier Martí, and M. García Guatas, El nacimiento del arte románico en Aragón. Arquitectura, Zaragoza, 1982, pp.142-149; 270-276; 308-310. 


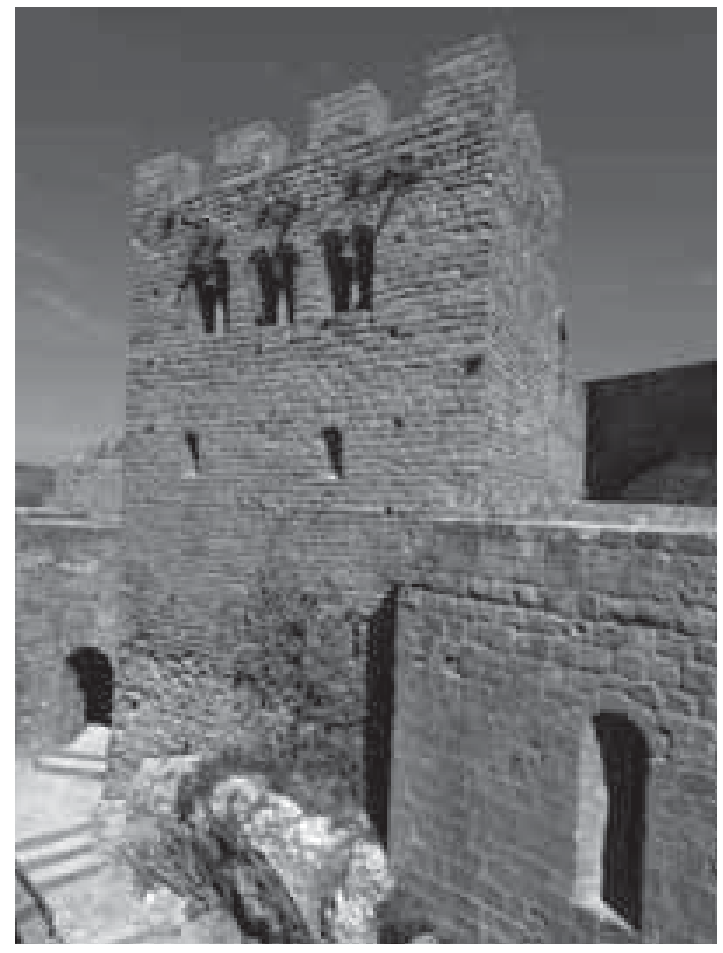

Fig. 2. Torre de la Reina, Loarre. Foto: A. García Omedes

the various architectonic elements of the building. Moreover, the proliferation of sculpture, including carved tympana, capitals, abaci, corbels, and metopes, distinguishes Jaca from the earlier examples, where these features are lacking.

Indeed, Jaca's impressive constructional qualities, with its sturdy yet elegant ashlar, communicate a sense of immutability, which undoubtedly were appropriate for the ambitions of the cathedral's patrons, those newly designated royals, the building project thus being a metaphor for the political enterprise of the kingdom. The building style introduced in Jaca became the dominant one in Altoaragón, establishing the standard for subsequent eleventh and twelfth century building in the region, as is evidenced by Jaca's role as model, in one form or another, for the castle-church of Loarre and the churches of San Adrián de Sasabe, Santa Cruz de la Serós, San Juan de la Peña, and San Salvador de Javierrelatre, among other buildings.

The introduction of this foreign manner of building in Aragón can be understood in context of some of the effective historical forces operative during the late eleventh century, particularly during the reign of Sancho Ramírez (1063-1094), which was marked by a well-defined political ambition to achieve some measure of Europeanization for his kingdom. ${ }^{20}$ Policies that favored Europeanization included the king's attempts to forge a close association with the papacy in Rome, including the adoption of the Roman liturgy in 1071 and the formal acknowledgement of Aragón's vassalage to Rome in 1089. Sancho also established affiliations with the great monastery of Cluny in Burgundy, which led to the Gregorian reform of Aragonese monasteries. ${ }^{21}$ Moreover, connections with the French nobility were es-

20 D. J. Buesa Conde, Sancho Ramírez, Rey de Aragoneses y Pamploneses (1064-1084), Zaragoza, 1996.

21 A. Durán Gudiol, La iglesia de Aragón durante los reinados de Sancho Ramírez y Pedro I (1062?1104), Rome, 1962, pp. 26-32; 52-54; A. I. LAPEÑA PAÚL, "Iglesia y monacato en el reinado de Sancho Ramírez", Sancho Ramirez, rey de Aragón, y su tiempo. 1064-1094, Huesca, 1994, pp. 135-139; D. J. BuESA CondE, Sancho Ramírez, Rey de Aragoneses y Pamploneses (1064-1084), Zaragoza, 1996, pp. 91-97; 147-150. 
tablished when Sancho Ramírez married Felicia de Roucy, daughter of the Count of Roucy and a lineal descendent of the Kings of France. It is interesting to note that Felicia's brother was influential in papal circles and had defended Pope Gregory VII at the side of the Normans. ${ }^{22}$ Furthermore, Sancho persuaded French warriors to participate in the Christian conquest of Muslimheld lands he was eager to annex and explicitly encouraged the French and other foreigners to establish themselves in the city of Jaca by virtue of concessions granted in the above-mentioned fueros. ${ }^{23}$

The Jaca cathedral that we see today (fig. 4) has suffered various renovations, transformations, and restorations to the Romanesque building that include the intro-

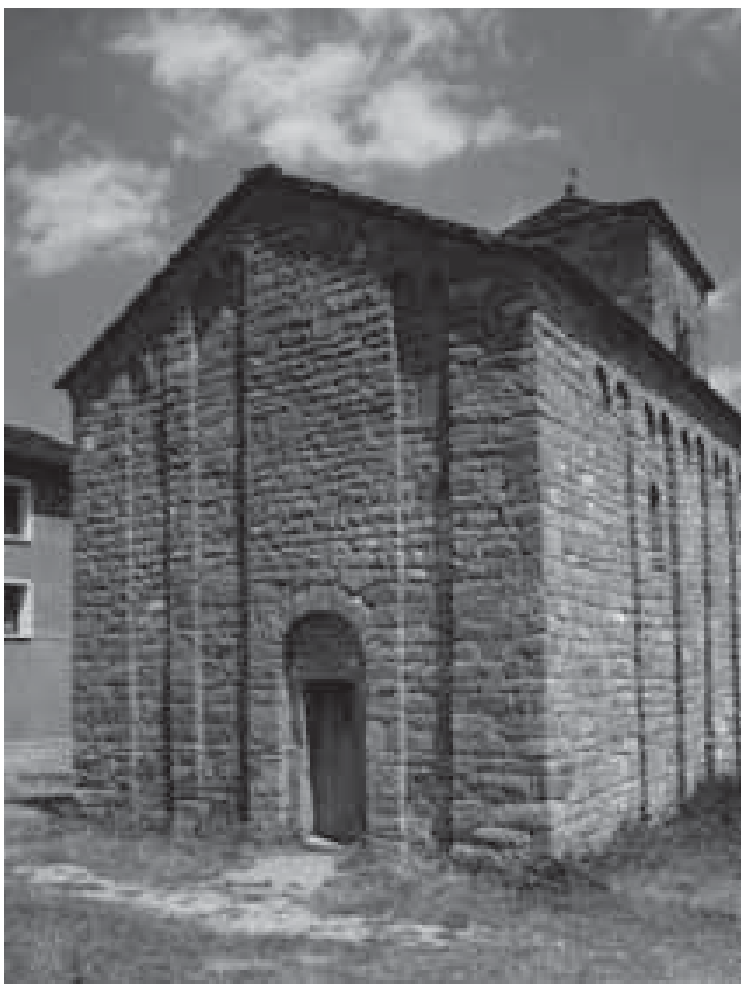

Fig. 3. San Caprasio, Santa Cruz de la Serós. Foto: D. L. Simon, Jr. duction of side chapels in the sixteenth century; ${ }^{24}$ the rebuilding of the cloister, between 1615 and 1620 , a project that lasted until $1693 ; 25$ the destruction, reconstruction, and elongation of the main apse between 1790 and $1792 ; ;^{26}$ and the addition of Renaissance vaulting to the nave

22 E. Sarasa Sánchez, "Sancho Ramírez, rey de Aragón y Navarra”, Sancho Ramírez, rey de Aragón, y su tiempo. 1064-1094, Huesca, 1994, p. 19; BuEsa Conde, Sancho Ramírez, Rey de Aragoneses y Pamploneses (1064-1084), Zaragoza, 1996, pp. 56-57; 103-105.

23 A. Ubieto Arteta, "Sobre demografía aragonesa del siglo XII", Estudios de Edad Media de la Corona Aragón, VII (1962), p. 590; J.M. LACARRA, “A propósito de la colonización 'franca' en Navarra y Aragón”, Colonización, parias, repoblación y otros estudios, Zaragoza, 1981, pp. 170-185; M. I. FALCón PÉREz, "Una ciudad de Franquicia: Jaca”, Sancho Ramírez, rey de Aragón, y su tiempo. 1064-1094, Huesca, 1994, pp. 108109; 114-120; M.I. Falcón PéRez, “Trayectoria medieval de Jaca en el seno de la Corona de Aragón”, Actas del XV Congreso de Historia de la Corona de Aragón, III, Zaragoza, 1994, pp. 13-22.

24 D.J. Buesa Conde, “Catedral de Jaca”, Las Catedrales de Aragón, Zaragoza, 1987, pp. 75-79; M. del C. Lacarra Ducay, Catedral y museo diocesano de Jaca, 1993, Brussels, pp. 36-45.

25 J.F. AznÁrez, "El claustro de la catedral de Jaca", Zaragoza, XIV (1961), pp. 171-179; D. J. BuESA Conde, "Catedral de Jaca", Las Catedrales de Aragon, Zaragoza, 1987, pp. 63-64; M. del C. LACARrA DuCAY, Catedral y museo diocesano de Jaca, 1993, Brussels, pp. 32-34.

26 D.J. Buesa Conde, “Catedral de Jaca”, Las Catedrales de Aragon, Zaragoza, 1987, pp. 66-68; M. del C. Lacarra Ducay, Catedral y museo diocesano de Jaca, 1993, Brussels, pp. 16; 22; 46-48. 


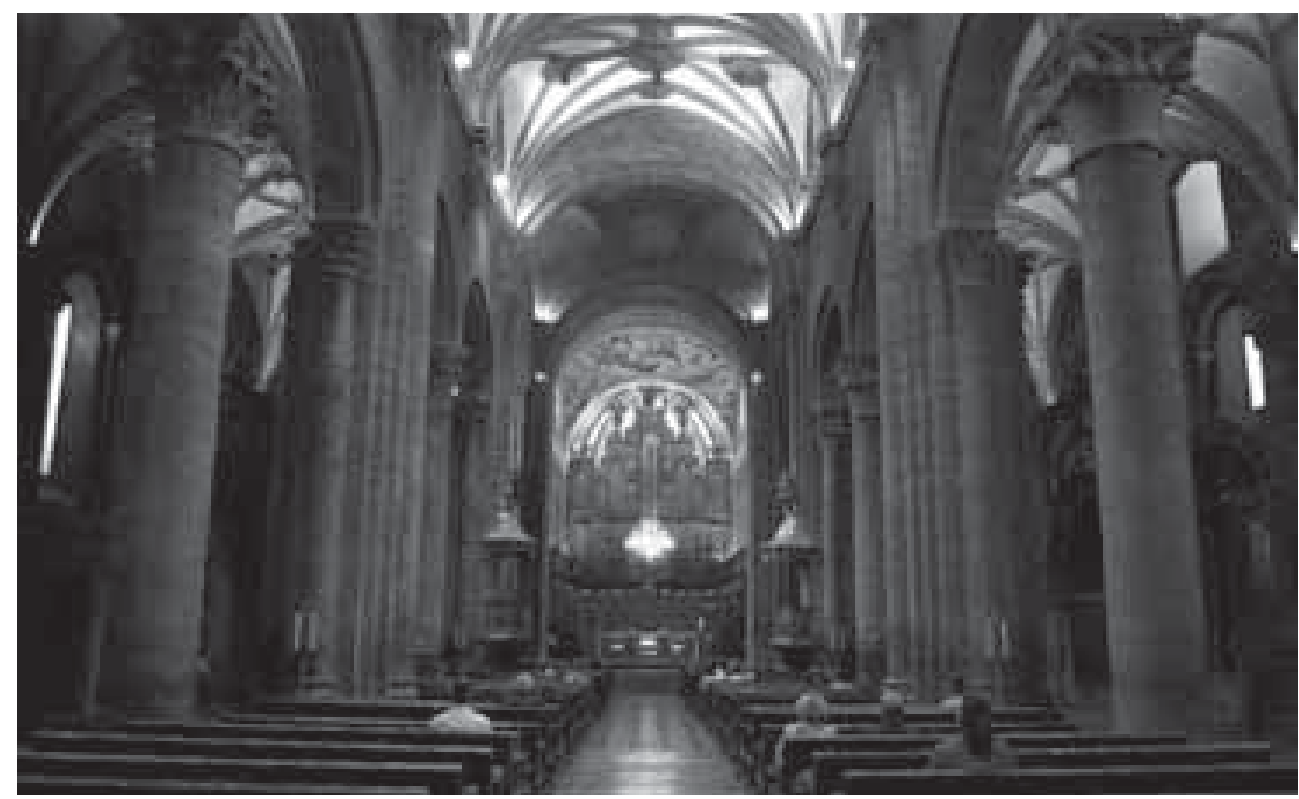

Fig. 4. Interior, Jaca cathedral. Foto: D. L. Simon, Jr.

and side aisles of the cathedral, which was undertaken throughout the sixteenth century, the side aisle vaults dating to 1520 and the central nave vault dating to between 1598 and $1601 .{ }^{27}$

What is surprising, given Jaca's history and art history is that there is in fact no evidence that the Romanesque cathedral of Jaca was originally vaulted. There are no buttresses and the building's alternating support system would not easily have supported vaults (fig. 5). No recent architectural historian, nor the architect in charge of the cathedral's latest restoration, which included a reroofing of the building, have been able to find any indications of early vaulting. ${ }^{28}$ This is in contrast to Francisco Iñiguez's claim of the 1930's that he saw evidence of vaulting in the course of his restorations to the cathedral. ${ }^{29}$ The presence of responds, which terminate at the level of the capitals, on the pair of central piers (figs. 4 and 5) led Cabañero Subiza to propose that the earliest project for the cathedral, i. e., the one described by Esteban Lorente, probably included groin vaults of the type that were

27 M.I. Oliván JARQue, “Obras y Reformas en la Catedral de Jaca en el siglo XVI, Homenaje a Federico Balaguer, Huesca, 1987, pp. 176-183; D.J. Buesa Conde, "Catedral de Jaca”, Las Catedrales de Aragón, Zaragoza, 1987, p. 64; M. del C. LACARra DucaY, Catedral y museo diocesano de Jaca, 1993, Brussels, pp. 18-19.

28 A. Canellas Lopez and A. San Vicente, Aragon roman, La Pierre-qui-Vire, 1971, pp. 156-157; D. J. Buesa Conde, “Catedral de Jaca”, Las Catedrales de Aragón, Zaragoza, 1987, p. 64; M. del C. LaCARra DucAY, Catedral y museo diocesano de Jaca, 1993, Brussels, pp. 61-19.

29 F. ÍñIguez, "La restauración de la Catedral de Jaca", Aragón, 117 (1935), p. 101. 
employed in the Lombard style buildings of the region (fig. 6). Cabañero concludes that the vaulting project was never completed because the proportions of the spaces to be vaulted were beyond the capabilities of the builders, but the fact that only one set of piers included responds suggests that the change in program was part of a larger transformation, one which resulted in the addition of sculpture and other decoration to the building. ${ }^{30}$ In any event, the lack of evidence of vaulting would seem to confirm the account of Pedro Villacampa, writing in 1562 and citing archival sources, who noted that in the 15 th century (in 1400, 1440, and 1447) there were a series of fires in the cathedral whose nave coverings were described as "todo era de fusta", that is to say, entirely of wood or timber. Moreover, the 1598 contract to vault the building specified that "the form and disposition of the vault must be composed in such manner to fit under the techumbre (wooden ceiling) and

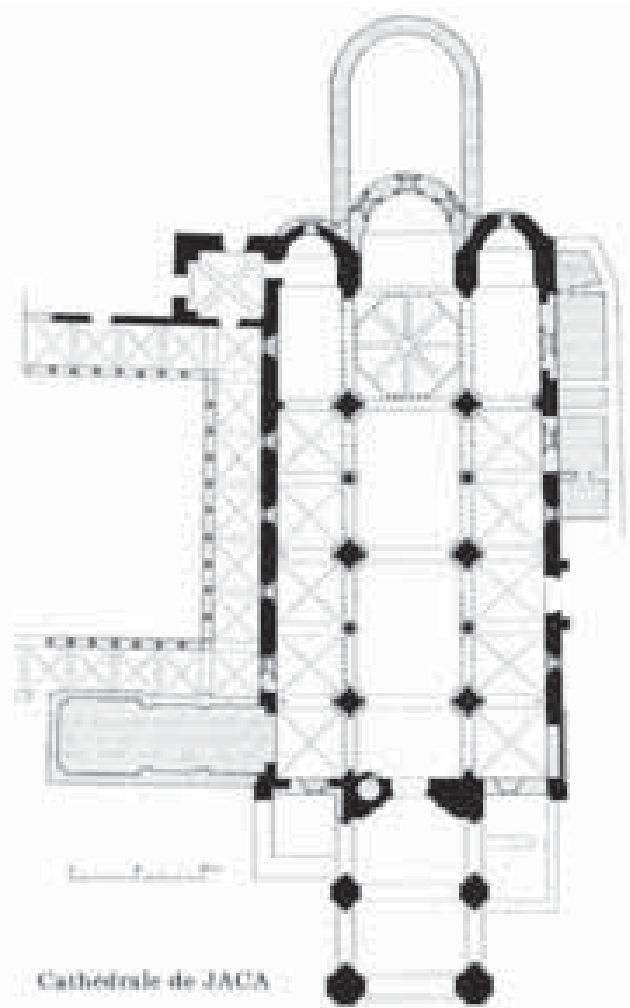

Fig. 5. Plan, Jaca cathedral. A. CANEllas LóPeZ and A. SAn Vicente, Aragon roman, La Pierre-qui-Vire, 1971, p. 154 under the roof," which is to say that the wooden framework still existed when the Renaissance vaults were added. ${ }^{31}$

Moreover, a number of Aragonese churches that in one way or another used Jaca as their model, to be sure much more modest in scale than the cathedral, seem never to have been vaulted nor to have been planned for vaulting: for example, Santa María de Iguacel (fig. 7), San Adrián de Sasabe (fig. 8), and San Salvador de Javierrelatre (figs. 9 and 10). Interestingly, these buildings had as

30 B. CABAÑero Subiza, "Precedentes musulmanes y primer arte cristiano", Las Cinco Villas aragonesas en la Europa de los siglos XI y XII: de la frontera natural a las fronteras políticas y socioeconómicas (foralidad y municipalidad), Zaragoza, 2005, pp. 235-237.

31 G. Llabrés, "El Noticiario de Pedro Villacampa, de Jaca”, Revista de Huesca, I (1903-04), pp. 179200; A. Canellas Lopez and A. San Vicente, Aragon roman, La Pierre-qui-Vire, 1971, p. 156; M.I. Olivan JARQUE, "Obras y Reformas en la Catedral de Jaca en el siglo XVI, Homenaje a Federico Balaguer, Huesca, 1987, pp. 167-183; D J. Buesa Conde, "Catedral de Jaca”, Las Catedrales de Aragón, Zaragoza, 1987, p. 62; M. del C. Lacarra Ducay, Catedral y museo diocesano de Jaca, 1993, Brussels, pp. 17-19; D. J. Buesa Conde, Jaca. Historia de una ciudad, Jaca, 2002, pp. 108-110. 


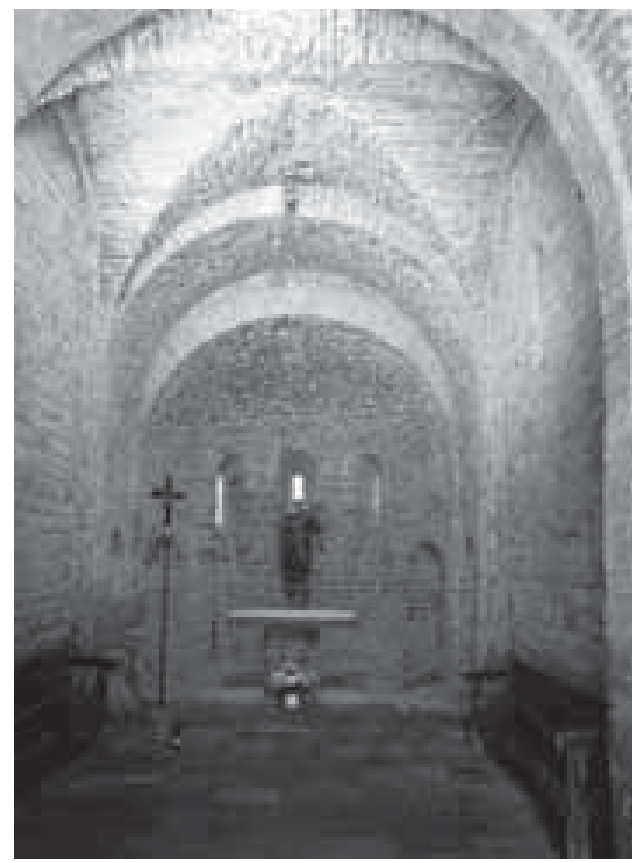

Fig. 6. Interior, San Caprasio, Santa Cruz de la Serós. Foto: D. L. Simon, Jr.

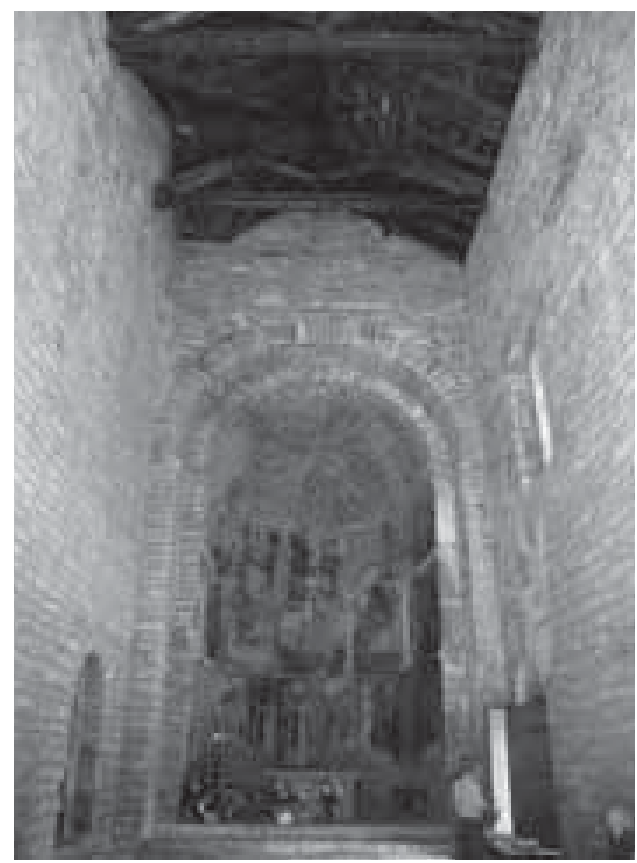

Fig. 7. Interior, Santa María de Iguacel. Foto: D. L. Simon, Jr.

their patrons members of the royal circle, who were also patrons of the cathedral. The inscription over the west door of Santa María de Iguacel relates that it was the ayo or eitán, that is, the tutor, of King Sancho Ramírez, Count Sancho Galíndez and his wife Urraca who were responsible for the construction of the building. ${ }^{32}$ And the most likely candidate to have been patron of the church of San Salvador de Javierrelatre was the lord of the village, Count Sancho Ramírez, illegitimate son of Ramiro I and half-brother of King Sancho Ramírez. ${ }^{33}$ It was the same Count Sancho who in 1105 financed the construction of a chapel in the precincts of Jaca cathedral, where he was to be buried. ${ }^{34}$ Thus, Javierrelatre, like

32 A. DurÁn Gudiol, "Las inscripciones medievales de la provincia de Huesca," Estudios de Edad Media de la Corona de Aragón, VIII (1967), pp. 45-109; J. CARo BARoJA, "Santa María de Iguácel. Su construcción y la inscripción conmemorativa de ésta”, Príncipe de Viana, XXXIII (1972), pp. 265-274. E. Zudaire Huarte, "Inscripción de Santa María de Iguácel," Príncipe de Viana, XXXV (1974), pp. 405-408; S. MoraleJo ÁlvaREZ, "Sobre las recientes revisiones de la inscripción de Santa María de Iguácel", Príncipe de Viana, XXXVII (1976), pp. 129-130.

33 M. Gómez Valenzuela, "Cinco iglesias románicas de escuela jaquesa”, Estudios de Edad Media de la Corona de Aragón, X (1975), pp. 581-589; A. UBIETo ARTETA, Historia de Aragón: La formación territorial, Zaragoza, 1981, p. 42. The tradition of Javierrelatre being a possession of Count Sancho Ramírez is related in Pedro IV, King of Aragon, The Chronicle of San Juan de la Peña: A Fourteenth Century Official History of the Crown of Aragon, ed. L. H. Nelson, Philadelphia, 1991, p. 17.

34 D.J. Buesa Conde, "Catedral de Jaca”, Las Catedrales de Aragon, Zaragoza, 1987, p. 59; M. del C. Lacarra Ducay, Catedral y museo diocesano de Jaca, 1993, Brussels, pp. 13-14. 


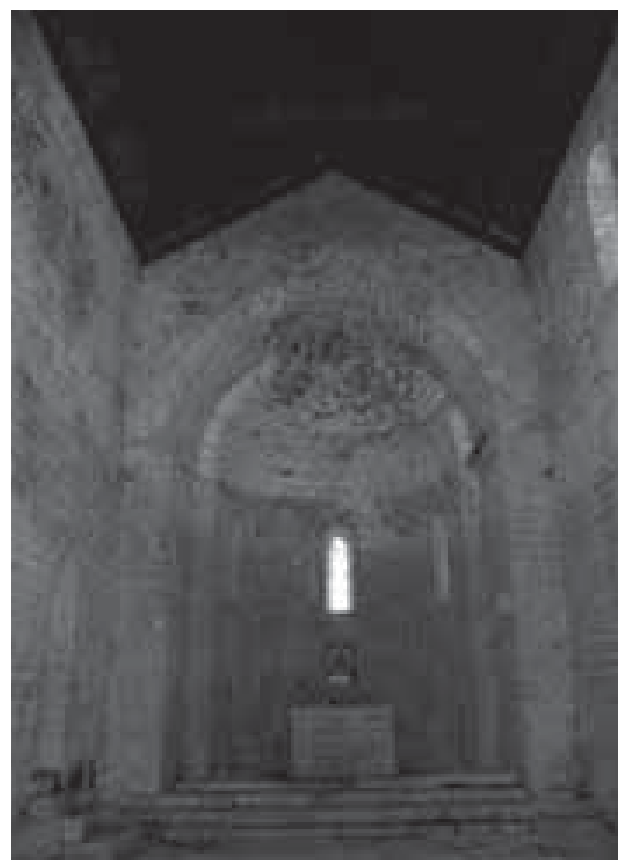

Fig. 8. Interior, San Adrián de Sasabe. Foto: D. L. Simon, Jr.

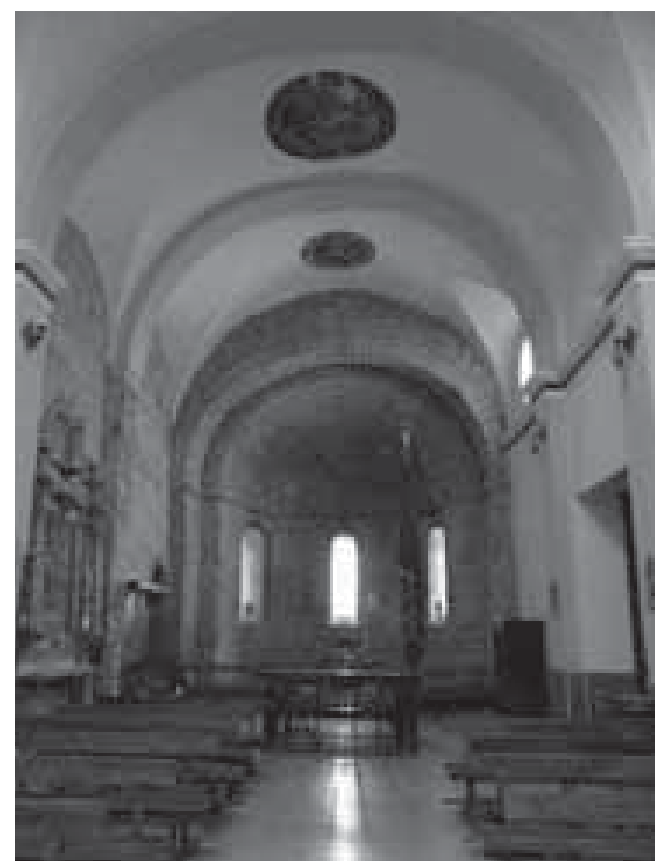

Fig. 9. Interior, San Salvador, Javierrelatre. Foto: D. L. Simon, Jr.

Iguacel, was patronized by members of the royal circle, who were also patrons of the cathedral of Jaca.

Moreover, further removed from Aragon, there exists a "copy" of Jaca in the form of the Castilian church of San Millán in Segovia, which both in plan and in the distribution of its architectonic features would seem to be based on Jaca (figs. 11 and 5), and it is noteworthy for our purposes that the church of San Millán was also originally unvaulted. The similarities between the two churches can perhaps be explained by virtue of the fact that Sancho Ramírez's son, Alfonso I, el Batallador, king of Aragon from 1104 to 1134 and who also reined in Castile between 1111 and 1126, was particularly well disposed to the city of Segovia, where an Aragonese garrison was stationed. ${ }^{35}$

The apparent proclivity for unvaulted spaces in Jaca cathedral and churches related to it appears anomalous among the group of pilgrimage road churches mentioned above to which in other ways Jaca bears such strong connections, San Isi-

35 J. de Contreras, Marqués de Lozoya, "Influencias aragonesas en el arte segoviano", Seminario de Arte Aragonés, V (1953), pp. 7-11; L.M. DE LoJENDIO and A. RodRIGUEz, Castille romane 2, La Pierre-quiVire, 1966, pp. 207-242; J.M. MERINo De CÁCERES, “La iglesia de San Millán de Segovia y su parentesco con la catedral de Jaca”, Estudios Segovianos, 102 (2002) pp. 317-350; J.F. Esteban Lorente, “La metrología y sus consecuencias en las iglesias de la Alta Edad Media española. IV. El románico del último tercio del siglo XI", Artigrama , XXIII (2008), pp. 396-401. 


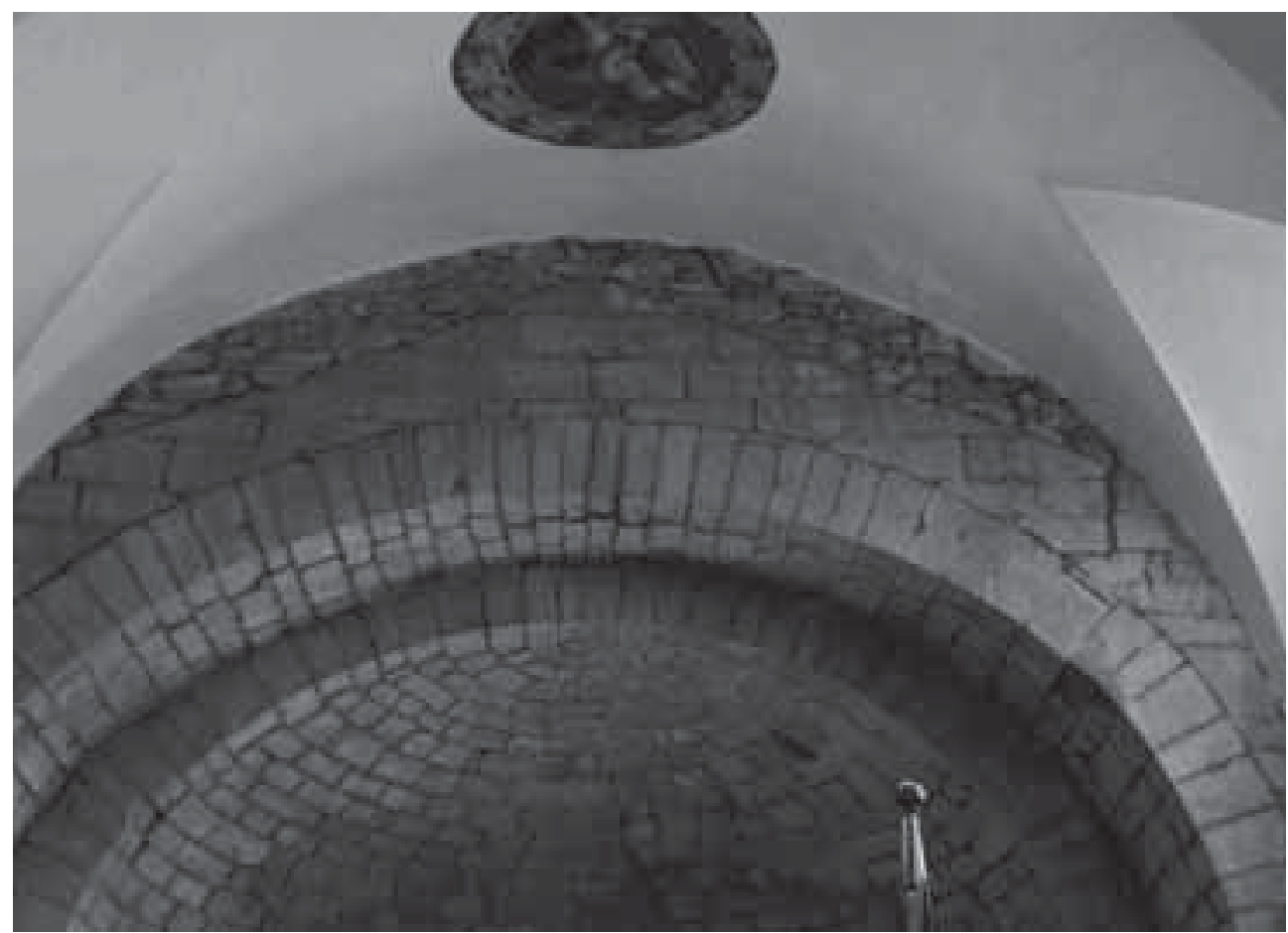

Fig. 10. Interior, detail, San Salvador, Javierrelatre. Foto: D. L. Simon, Jr.

doro in Leon, San Sernin in Toulouse, San Martín in Frómista, and the cathedral of Santiago de Compostela, since one of the primary features of these churches is that they are stone vaulted, in fact finely and elegantly vaulted. These stone vaults are often cited as obvious manifestations of the introduction of a French current in the Peninsula and of the penchant for reviving Roman forms, a penchant that is particularly evident at Jaca in so many other aspects of the cathedral's construction. So strong is the reliance on antique models that it has been convincingly claimed by Serafín Moralejo Álvarez that the style of much of the sculpture at Jaca developed from a careful study of antique prototypes by sculptors who worked there, in particular of a second-century Roman sarcophagus, today in the Museo Arqueológico Nacional in Madrid, which was brought there from Husillos, some twenty-five kilometers from Frómista, where the Jaca sculptors also worked and where evidence of the sarcophagus's formal impact was also demonstrated by Moralejo. ${ }^{36}$

36 S. Moralejo Álvarez, "Sobre la formación del estilo escultórico de Frómista y Jaca", Actas del XXIII Congreso Internacional de Historia del Arte, I, Granada, 1976, pp. 427-434; S. Moralejo Álvarez, "La sculpture romane de la Cathédrale de Jaca. État des questions", Les Cahiers de Saint-Michel de Cuxa, 10 (1979), pp. 84-88; F. Prado-VILAR, "Saevum facinus: estilo, geneolgía y sacrificio en el arte románico español”, Goya, 324 (2008), pp. 173-199. 


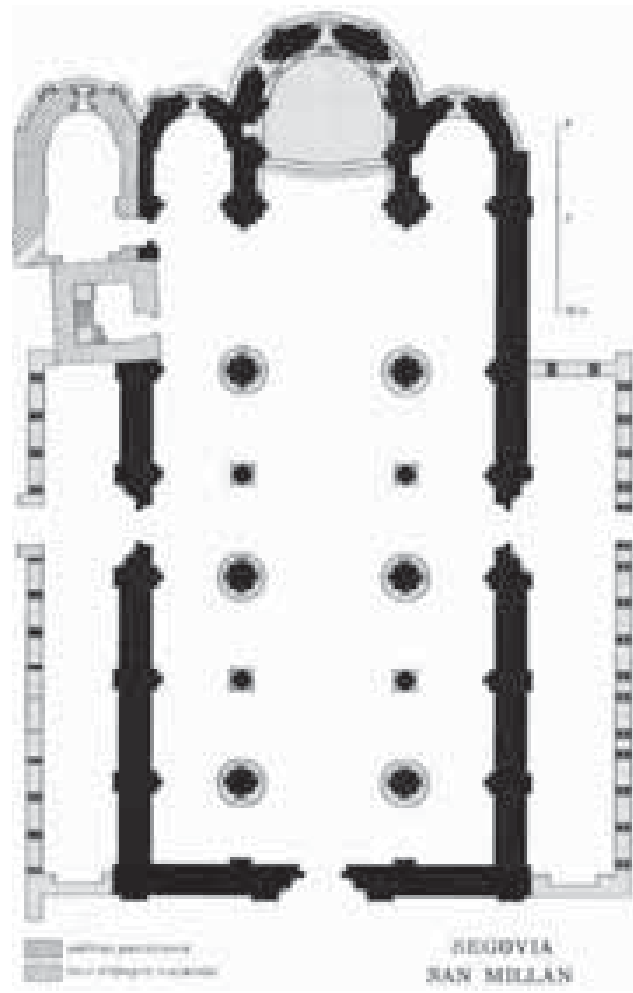

Fig. 11. Plan, San Millán, Segovia. L.M. DE LoJEndio and A. Rodríguez, Castille romane 2, La Pierre-qui-Vire, 1966, p. 238

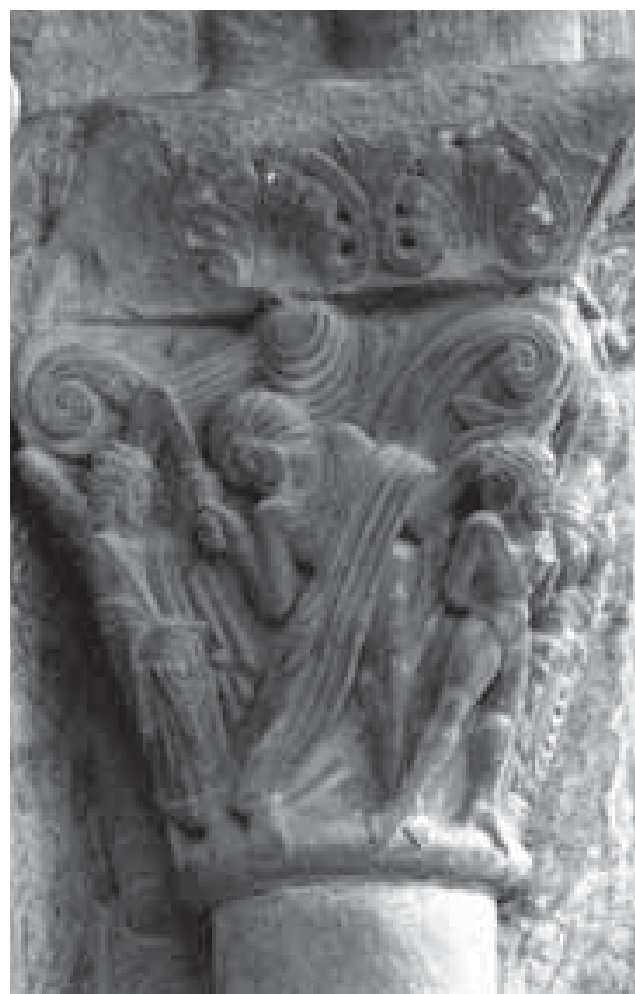

Fig. 12. Capital, south portal, Jaca cathedral. Foto: A. García Omedes

The reliance on the antique past is indeed profound at Jaca, sufficiently so for Marcel Durliat to describe the sculptor of a south portal capital depicting the Sacrifice of Isaac (fig. 12) as que on peut qualifier d'exceptionnel. Il se distingue de ses contemporains des environs de 1100 par l'attention qu'il porte à l'enseignement de l'antiquité classique. En partant d'analyses aiguës de sarcophages romains, il introduisit le 'nu hérö̈que'dans l'art chrétien et il fit accomplir des progrès marqués à la composition roman. Durliat allows for the possibility that this sculptor's work might be considered one of the sources of the Renaissance of the twelfth century, a remarkable claim indeed. ${ }^{37}$

The interest in antique forms at Jaca is evident in both architecture and sculpture and cuts across all workshops at the cathedral, from the earliest ones responsible for the apses and portals to the latest ones, in the cloister and its dependencies. ${ }^{38}$ For

37 M. Durliat, “Les Pyrénées et l'art roman”, Les Cahiers de Saint-Michel de Cuxa, 10 (1979), pp. $170-171$.

38 S. Moralejo Álvarez, "La sculpture romane de la Cathédrale de Jaca. Etat des questions”, Les Cahiers de Saint-Michel de Cuxa, 10 (1979), pp. 85-93; J.L. Senra Gabriel y Galán, “Hercules versus Cristo?: una possible simbiosis iconográfica en el románico hispano”, Quintana, I (2002), pp. 275-283. 


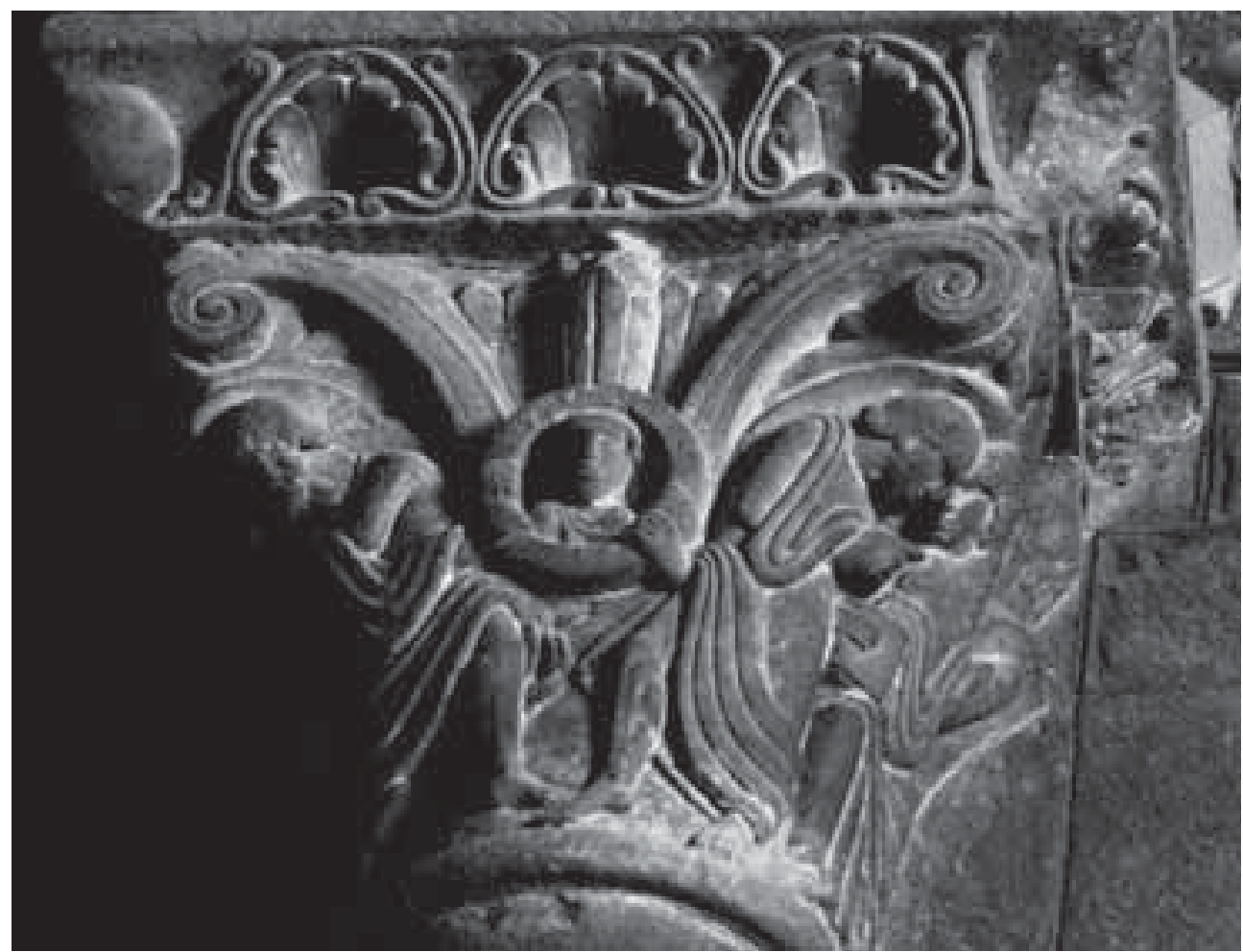

Fig. 13. Capital, interior, Jaca cathedral. Foto: D. L. Simon, Jr.

example of an early work, we can compare the motif of the imago clipeata on an interior capital of the cathedral (fig. 13), on the east side of the northwest crossing pier, with representations of the same subject on many Roman and Early Christian sarcophagi, such as the one found today in San Pedro el Viejo in Huesca (fig. 14), reemployed to house the body of King Ramiro II, el monje, son of Sancho Ramírez, who died in $1157,{ }^{39}$ or on a sarcophagus of about 230 A.D. in the Dumbarton Oaks Collection, perhaps a closer example, since the figures supporting the clipeata are erect, as they are on the Jaca capital. ${ }^{40}$ Neither example is meant to propose an actual source of the Jaca formula, but to suggest that the motif was a common one in the art of antiquity. Another example, worth citing because it demonstrates that the reliance on the Roman past also can be seen in the later works of the cathedral, is the faun on a capital currently used as a support for the altar of the south apse but

39 A Hernández Vera and A. González Blanco, «Sarcófago de Ramiro II el Monje», La Religión romana en Hispania, Madrid, 1981, pp. 353-362.

40 S. Moralejo Álvarez, "La sculpture romane de la Cathédrale de Jaca. État des questions", Les Cahiers de Saint-Michel de Cuxa, 10 (1979), pp. 87; S.C. Simon, "Iconografía de un capitel del claustro de la catedral de Jaca", Actas del XV Congreso de Historia de la Corona de Aragón, III, Zaragoza, 1994, p. 42. 


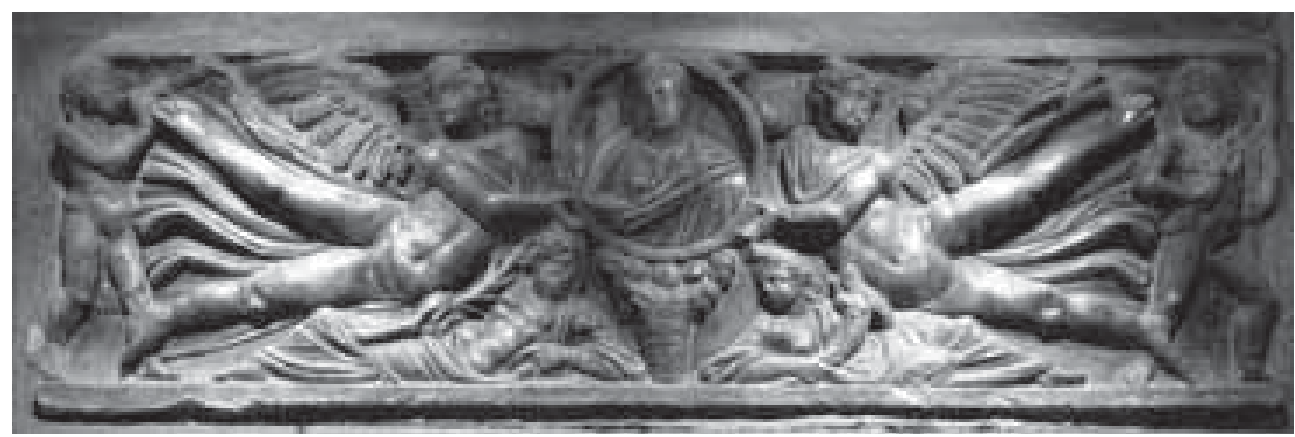

Fig. 14. Sarcophagus of Ramiro II, San Pedro el Viejo, Huesca. Foto: A. García Omedes

probably originally part of the now-dismantled cloister, which relies on another Roman sarcophagus motif, where the erotic, or at least suggestive, gesture of the hand on the faun's buttocks is reminiscent of that of the representation on the capital. ${ }^{41}$

Another capital (fig. 15), today in the church of Santiago in Jaca but probably also related to the cloister program, demonstrates that those responsible for the cathedral's decoration knew not only the style and motifs of Roman examples, but also their significance, that is that they were engaged in more than the blind copying of ancient works. The capital, which can be compared on the basis of style to the Ramiro II sarcophagus mentioned above, has been shown by Sonia C. Simon to include a mixture of representations of seasons and planets, comparable to both Roman calendar representations in manuscripts and to images on Roman sarcophagi. ${ }^{42}$

Noteworthy as well to demonstrate the willingness of the Jaca sculptors or program designers to explore the significance of antique works is the cathedral's west portal, one of the most studied monuments of medieval Iberia, which contains, if not the first, certainly one of the first tympana in Europe (fig. 16). ${ }^{43}$ The Jaca

41 S.C. Simon, unpublished lecture on the Jaca cathedral cloister, Columbia University, 1980.

42 S.C. Simon, "Iconografía de un capitel del claustro de la catedral de Jaca", Actas del XV Congreso de Historia de la Corona de Aragón, III, Zaragoza, 1994, pp. 421-436.

43 A.K. PorTER, "The Tomb of Doña Sancha and the Romanesque Art of Aragon", Burlington Magazine, 45 (1924), pp. 165-179; ID., Spanish Romanesque Sculpture. I, New York, 1928, p. 70; 35; L. TorRes BALBÁs, "La escultura románica aragonesa y el crismón de los tímpanos de las iglesias de la región pirenaica", Archivo español de arte y arqueologia, 2 (1926), p. 290; M. Dolç, "Tres inscripciones de la catedral de Jaca", Pirineos, 9 (1953), p. 423; J. VIVEs, "Las leyendas epigráficas del tímpano de Jaca", Hispania sacra, 9 (1956), pp. 391-394; A. DurÁn GUdIol, "Las inscripciones medievales de la provincia de Huesca", Estudios de Edad Media de la Corona de Aragón, 8 (1967), pp. 100-103; A. Canellas Lopez and A. San Vicente, Aragon roman, La Pierre-qui-Vire, 1971, pp. 159-160; S. Moralejo Álvarez, "Aportaciones a la interpretación del programa iconográfico de la catedral de Jaca", Homenaje a don José María Lacarra de Miguel en su Jubilación del Profesorado. Estudios medievales, I, Zaragoza, 1977, pp. 173-198; J.M. CAAMAÑo MARTíneZ, "En torno al tímpano de Jaca", Goya, 142 (1978), pp. 200-207; S.H. CAldwell, "Penance, Baptism, Apocalypse: The Easter Context of Jaca Cathedral's West Tympanum”, Art History, 3 (1980), pp. 23; D. Ocón Alonso, "Problemática del crismón trinitario", Archivo Español de Arte, 56 (1983), pp. 242-263; D. Ocón Alonso y P. Rodríguez Escudero, "Los tímpanos de Jaca y Santa Cruz de la Serós, una pretendida relación modelo- 


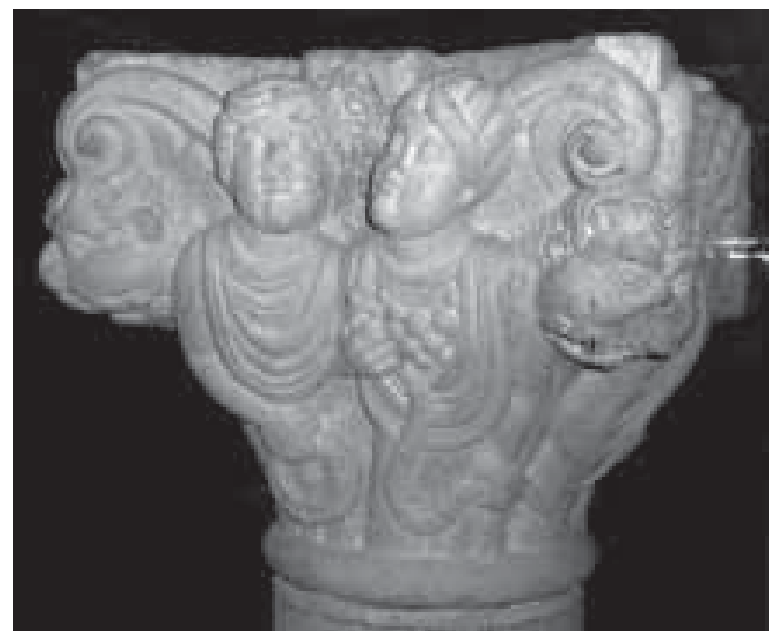

Fig. 15. Capital, Church of Santiago, Jaca. Foto: D. L. Simon, Jr. tympanum is decorated with a central motif, the chrismon (fig. 17), comprised of a chi and a rho, the first two letters of Christ's name in Greek. The Jaca chrismon is undoubtedly derived, once again, from a device commonly depicted on Early Christian sarcophagi, ${ }^{44}$ for example, on one represented in the collection of the Museo Pio Cristiano in the Vatican (fig. 18). Both chrismons are of the type that includes an alpha and an omega, the first letters of Christ's name in Greek, in reference to Christ's characteriza-

tion of himself in Revelation 22:13 as the beginning and the end. On both the Jaca tympanum and the Early Christian example the branches of the letters and the chrismon's circumference appear to be formed of tied reeds or bundled stalks and each chrismon is decorated with eight fleurettes.

Two lions flank the chrismon to create a striking formal and an aesthetically and thematically integrated composition. A snarling lion on the right side of the tympanum stands over a bear and a basilisk, while on the left, a more benign lion stands above a prostrate human figure clutching a serpent. The iconography of the tympanum is related to the function of the porch at Jaca, where the public rites of penitence would have taken place, and as well to Jaca's role as royal city and episcopal seat. $^{45}$

copia", Actas del V Congreso Español de Historia del Arte. Barcelona, 1984, pp. 259-263; R. FAVREAU, B. Mora, and J. Michaud, Corpus des inscriptions de la France médiévale, 10, Chrismes du sud-ouest. Paris, 1985, pp. 6-7; J.F. Esteban Lorente, "Las inscripciones del tímpano de la Catedral de Jaca", Artigrama 10 (1993), pp. 143-161; D.L. Simon, "El tímpano de la Catedral de Jaca", Actas del XV Congreso de Historia de la Corona de Aragón, III (1994), pp. 405-419; C.L. Kendall, "The Verse Inscriptions of the Tympanum of Jaca and the PAX Anagram", Mediaevalia 19 (1996), pp. 405-434; R. FAVREAU, "Les inscriptions du tympan de la Cathédrale de Jaca", Académie des Inscriptions et Belles-Lettres (1996), pp. 535-560; C.L. KENDALL, Allegory of the Church, Toronto, 1998, pp. 122-138; J.F. EsTEBAn LoREnTE, "El tímpano de la Catedral de Jaca (continuación)", Aragón en la Edad Media, XIV-XV (1999), pp. 451-472.

44 S. Moralejo Álvarez, "San Martín de Frómista, en los orígenes de la Escultura Románica Europea," Jornadas sobre el Románico en la Provincia de Palencia, Palencia, 1986, p. 32.

45 S. Moralejo Álvarez, "Aportaciones a la interpretación del programa iconográfico de la Catedral de Jaca," Homenaje a don Jose María Lacarra de Miguel, 1 (1977), pp. 173-198; S. Moralejo Álvarez, "La sculpture romane de la Cathédrale de Jaca. Etat des questions", Les Cahiers de Saint-Michel de Cuxa, 10 (1979), pp. 93-97; D. L. Simon, "El tímpano de la Catedral de Jaca", Actas del XV Congreso de Historia de la Corona de Aragón, III (1994), pp. 405-419. 


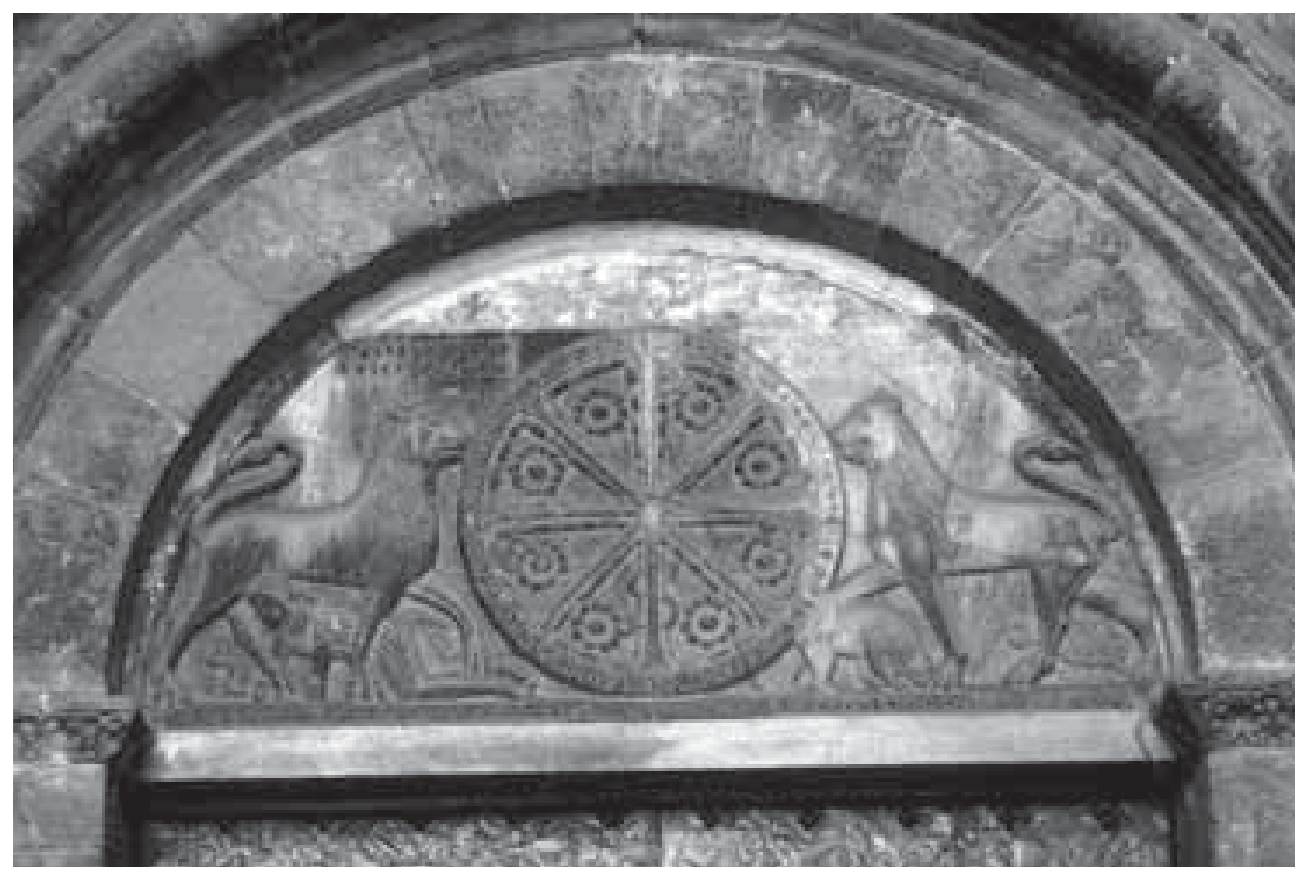

Fig. 16. Tympanum, west portal, Jaca cathedral. Foto: D. L. Simon, Jr.

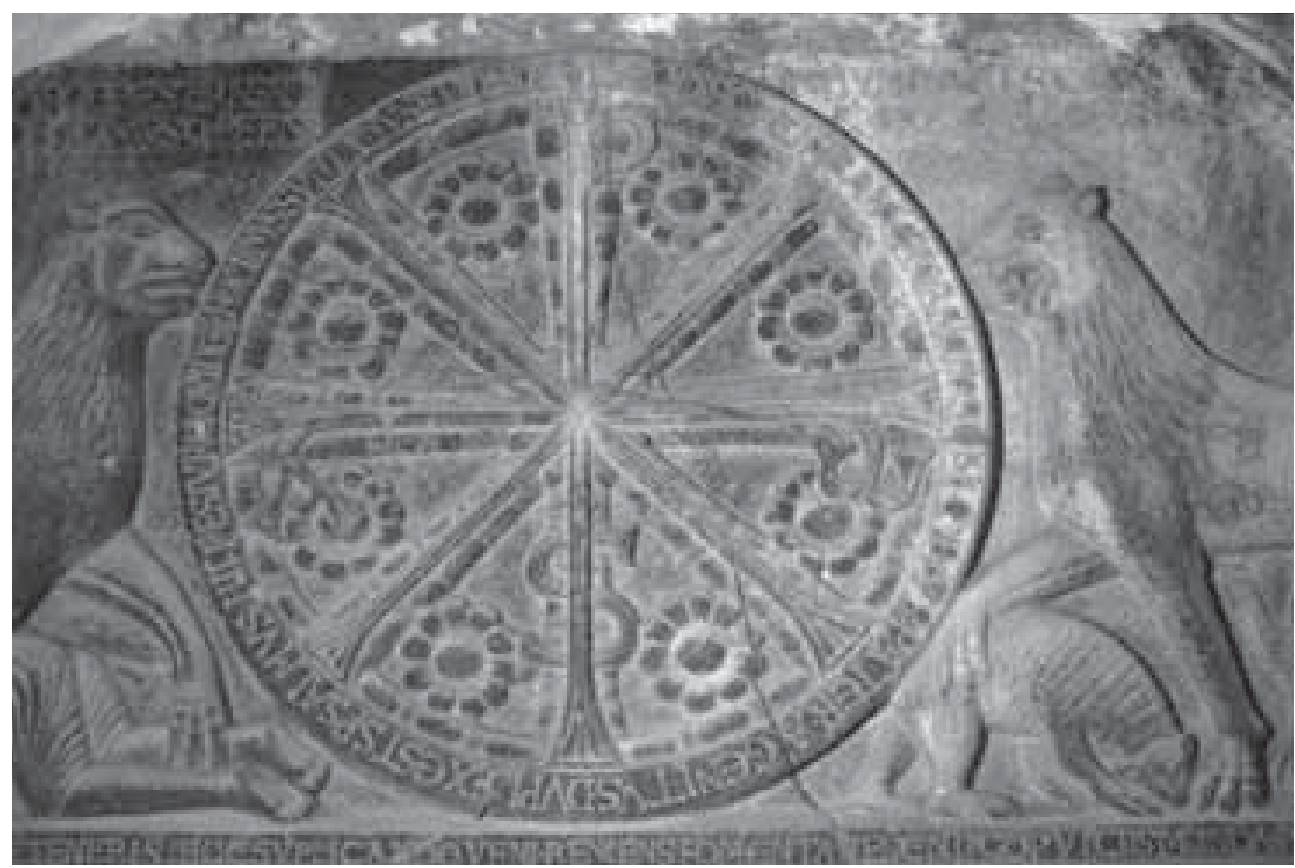

Fig. 17. Tympanum, west portal, detail of chrismon, Jaca cathedral. Foto: D. L. Simon, Jr. 


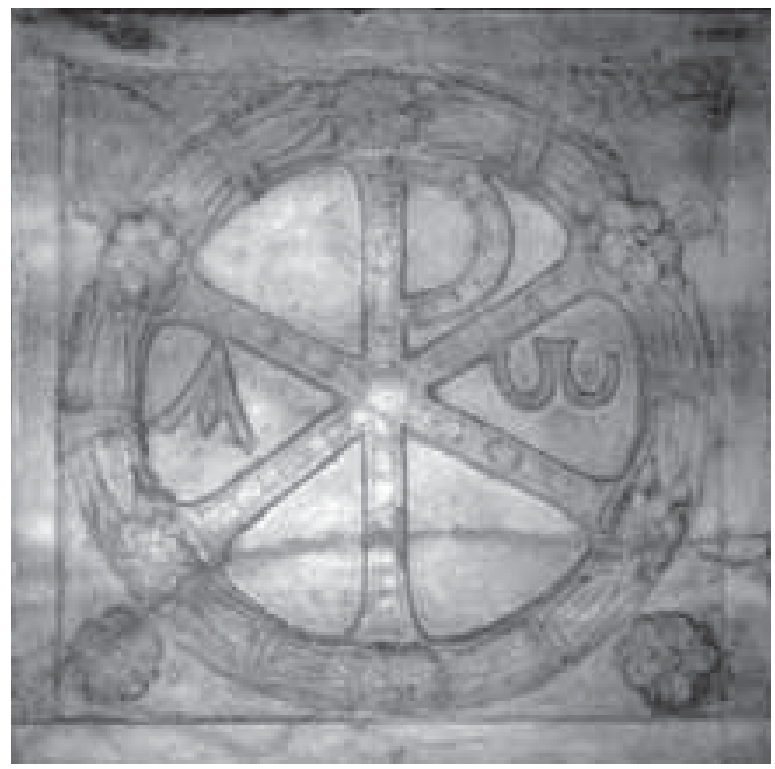

Fig. 18. Sarcophagus, Museo Pio Cristiano, Vatican. Foto: D. L. Simon, Jr.
The complex inscriptions that decorate the Jaca tympanum have been well studied. Those behind the lions and on the lintel concern penance, promising rewards for those who practice the penitential rites and punishment for those who ignore them. Although the inscription surrounding the chrismon has stirred intense scholarly debate, there is general agreement on its fundamental nature. This inscription interprets the chrismon as a sign of the Trinity: + HAC IN SCVLPTVRA LECTOR SIC NOSCERE CVRA, P PATER. A GENITVS. DVPLEX EST SPirituS ALMVS, HII TRES IVRE QVIDEM DOMINVS

SVNT VNVS ET IDEM ("In this sculpture, reader, take care to understand [the symbolism] in this way: P is the Father, A is the Son, the double letter is the Holy Spirit. These three are indeed rightly one and the same, the Lord.") Earlier scholarship held that the Jaca artists or program designers misidentified the Greek letters that form Christ's monogram as Latin ones that signify the Trinity, that they thus replicated antique models without full knowledge of the significance of what they were imitating: P (rho) denotes the Father, A (alpha) the son, while the Spirit is indicated by the double letter, the X. But, as recent studies by Calvin Kendall and Juan Francisco Esteban Lorente have shown us, the letters mentioned in the inscription, the $\mathrm{P}$, the $\mathrm{A}$, and the $\mathrm{X}$ (the double letter) also signify PAX, or peace. ${ }^{46}$ As Kendall explains: "The door of eternal salvation or 'peace', which is Christ, lies open to the public penitent who follows the penitential instruction of the verses of the lintel." ${ }^{\prime 7}$ As such, the designers of the Jaca program, rather than offering an interpretation of the chrismon because of their lack of knowledge of its meaning, in fact understood the original meaning of the chrismon, even as they expounded on

46 J. F. Esteban Lorente, "Las inscripciones del tímpano de la Catedral de Jaca", Artigrama 10 (1993), pp. 143-161; C.L. Kendall, "The Verse Inscriptions of the Tympanum of Jaca and the PAX Anagram", Mediaevalia 19 (1996), pp. 405-434; ID., Allegory of the Church, Toronto, 1998, pp. 122-138; J.F. EsTEBAN Lorente, "El tímpano de la Catedral de Jaca (continuación)", Aragón en la Edad Media, XIV-XV (1999), pp. 451-472.

47 C.L. Kendall, Allegory of the Church, Toronto, 1998, p. 129. 
it. Indeed, for some time Christian exegesis had shown an appreciation of the original significance of the chrismon. ${ }^{48}$ Moreover, Kendall has demonstrated that the use of classical Latin for the inscriptions, which are formed of leonine hexameters and employ an internal rhyme, was both erudite and intelligent. And, to demonstrate the sophistication with which the Jaca program planners developed their ideas one need only recall José Vives's description of the inscription's author as well educated $^{49}$, Miguel Dolç's conclusion that he was a scholar trained in classical Latin, ${ }^{50}$ Esteban's observation that he knew the texts of the Holy Fathers of the Church, ${ }^{51}$ Kendall's appraisal of him as intentionally creating a puzzle, ${ }^{52}$ and Ocon's that he was creating a play on words. ${ }^{53}$

To return to the inscription, it seems clear that the duplex refers, not only to a letter, but also to the concept of the double nature of Christ. Christ's nature was of constant concern and the subject of dispute throughout the Christian world, including Spain, where the theological issues of Christ's nature were discussed from earliest times. It was, at least in part, the discussion of Christ's nature and the concern about how Christ's relationship to God the Father should be understood, a revival of the old Adoptionist controversy, that led to the introduction of the Roman rite in Spain. The Roman liturgy, in fact, was introduced into Spain within the diocese of Jaca; this occurred in $1071,{ }^{54}$ probably within the same decade as the establishment of a bishopric and the commencement of the decoration of the cathedral. The adoption of the Roman liturgy can also be related to King Sancho Ramirez's concern to align himself with the papacy, the tympanum's meaningful program thus paralleling the ambitions of its patrons.

There is further evidence that the iconography of the tympanum was conceived because of special circumstances at Jaca. During the period when the cathedral was being built and its sculptural program being carved, Jaca was the capital of the socalled Reconquest, the attempt to expel Moslem invaders from Spain. In fact, it was the Moslem presence in much of what we now call Aragon that led to the founding of the Kingdom's capital at Jaca. Menéndez-Pidal has shown that the chrismon, by virtue of its association with the divinely-inspired victory of Constantine, the first

48 R. BARTAL, "The survival of early christian symbols in $12^{\text {th }}$ Century Spain", Príncipe de Viana, XLVIII (1987), pp. 299-316.

49 J. ViVES, «Las leyendas epigráficas del tímpano de Jaca», Hispania sacra, 9 (1956), pp. 391-394.

50 M. Dolç, «Tres inscripciones de la catedral de Jaca», Pirineos, 9 (1953), p. 423.

51 J.F. Esteban Lorente, "Las inscripciones del tímpano de la Catedral de Jaca", Artigrama 10 (1993), pp. 143-161; ID., "El tímpano de la Catedral de Jaca (continuación)", Aragón en la Edad Media, XIV-XV (1999), pp. 451-472.

52 C.L. Kendall, Allegory of the Church, Toronto, 1998, p. 129.

53 D. Ocón Alonso, «Problemática del crismón trinitario», Archivo español de arte, 56 (1983), pp. 242-263.

54 A. Ubieto Arteta, «La introducción del Rito romano en Aragón y Navarra», Hispania sacra, I (1948), pp. 299-324; A. DurÁn Gudiol, La iglesia de Aragón durante los reinados de Sancho Ramírez y Pedro I (1062?1104), Rome, 1962, pp. 11-12; 28-29; D.J. Buesa Conde, El rey Sancho Ramírez, Zaragoza, 1978, pp. 46-48. 
Christian Roman emperor, was understood in Aragon during the eleventh century as a sign of Christian success. ${ }^{55}$ The chrismon's historical importance as symbol of Constantine's triumph would have been particularly appropriate for use at Jaca at a time when the city's energies and forces were occupied in the conquest, a Christian campaign against pagan forces whose parallel to the Constantinian achievement is obvious. In an apparent first-hand account and according to his biographer, Bishop Eusebius of Caeserea, while Constantine was preparing to battle his fellow Tetrarch Maxentius for control of the Western Empire, Constantine claimed to have seen a sign in the sky in the form of the monogram of Christ, formed by the Chi Rho, and to have had a dream in which Christ himself assured him of his victory over Maxentius, a rout which took place at the Milvian Bridge in Rome in 312 after Constantinian had ordered his troops to paint the sign of Christ, the chrismon, on their shields and their standards. ${ }^{56}$

Thus, the tympanum at Jaca, and probably the entire decorative enterprise of the cathedral, was conceived by a person or persons trained in classical texts, with an understanding of the meaning and significance of some antique representations and writings, and aware of the central political and religious concerns of the realm. Both style and iconography suggest a conscious Romanization, one that parallels the historical events of Jaca in the late $11^{\text {th }}$ century. ${ }^{57}$

So, the paradox is that in all ways, except for its ceiling, Jaca adopted the style of the moment, ashlar-masonried and aisled churches decorated with architectonic ranges of sculpture that took as their model antique Roman works. But, in choosing to build a timber-framed roof, the designers or builders of the cathedral seem to have turned their backs on both the foreign manner of building they adopted and local practice, that is, the traditional building forms of the region. One should remember that those early Aragonese buildings of the Lombard or First Romanesque style, for example San Caprasio in Santa Cruz de la Serós (fig. 6) from which in so many of its features Jaca cathedral seems to have differed, were, in fact, often stone vaulted. Thus, vaulting per se was not an unknown or lost art in the region and we can only suppose that the Jaca designers, architects, or builders consciously chose not to use it. ${ }^{58}$

55 G. MenéndeZ-Pidal, «El lábaro primitivo de la reconquista», Boletín del la Real Academia de la Historia, 136 (1955), 275-296. See also A. SENÉ, «Quelques remarques sur les tympans romans à chrisme en Aragon et Navarre», in P. Gaillais and Y. Riou, Mélanges offerts à René Crozet. I, Poitiers, 1966, p. 370; D. Ocón Alonso, Tímpanos románicos españoles, II, Madrid, 1987, pp. 46-49; 54-61; R. BARTAL, "The survival of early christian symbols in $12^{\text {th }}$ Century Spain", Principe de Viana, XLVIII (1987), pp. 299-316.

${ }^{56}$ EusebIo, Life of the Blessed Emperor Constantine: From AD 306 to 337, Merchantville, 2009.

57 S.H. Caldwell, "Penance, Baptism, Apocalypse: The Easter Context of Jaca Cathedral's West Tympanum", Art History, 3 (1980), pp. 25-40; R. BARTAL, "The survival of early christian symbols in $12^{\text {th }}$ Century Spain, Príncipe de Viana, XLVIII (1987), pp. 299-316.

58 M. Durlat, "La sculpture romane à Jaca", Comptes-rendus de séances de l'Académie des Inscriptions et Belles Lettres, CXXII (1978), p. 395. 
I would like to suggest that, at the time the cathedral of Jaca was built, the presence of a wooden roof at Jaca, seemingly such an anomaly amid the cathedral's antiquating decorative and structural forms, might well have been seen as much an antique revival as a stone vault would have been. There is a particular class of antique buildings where the wooden roof virtually serves to define the form, that is, the basilica type, and in particular the Early Christian basilica. ${ }^{59} \mathrm{I}$ think the specific reference at Jaca might well be to Saint Peter's in Rome, built by the emperor Constantine in the fourth century, the same emperor who is referred to on the tympanum of Jaca.

But, why at this time would Jaca have gone in such an independent direction? Thirty years ago Serafín Moralejo wondered about "le problème de savoir quelles ont pu être les conditions culturelles qui favorisèrent une 'renaissance'si précoce et si singulière... dans la cathédrale du royaume aragonais, récemment constitué." ${ }^{60} \mathrm{I}$ think one of the possible answers might well lie in the last phrase of his query, that is, by recognizing that the newness of the kingdom was of central importance to all aspects of the royal enterprise, including the design of the cathedral. After all, the cathedral of Jaca was dedicated to Saint Peter, the same invocation as that of the emblematic Early Christian basilica in Rome, and the introduction of the Roman rite in Aragón in 1071 is coeval with the founding of the bishopric and the expansion of the building program in Jaca, events which occurred just after King Sancho Ramírez's journey to Rome in 1068. This trip was made when he was twenty-five, only a few years after he assumed the throne, and when he placed Aragón under protection of the Holy See. His continued interest in aligning himself with the papacy resulted in formalizing vassalage to Rome in $1089,{ }^{61}$ at which time Pope Urban II refers to the King as "devotísimo servidor del beato Pedro." ${ }^{62}$ In fact, it is precisely toward the end of his reign, in the late 1080's and early 1090's, when I think the construction of the cathedral was being pursued most actively, that letters between Sancho Ramírez and the pope proliferate.

59 San Vicente, in claiming that both the sculptor and architect of the cathedral were inspired by Italian or Byzantine models, recognizes the conception of the original building as basilican: A. CANELLAS LóPEZ and A. SAn Vicente, Aragon roman, La Pierre-qui-Vire, 1971, p. 157. Lacarra notes that the original covering of the Jaca nave would have been of the same type as that of the Early Christian basilica: M. del C. LACARRA DUCAY, Catedral y museo diocesano de Jaca, 1993, Brussels, p. 16.

60 S. Moralejo Álvarez, "La sculpture romane de la cathédrale de Jaca. État des questions", Cahiers de Saint-Michel de Cuxa, 10 (1979), p. 91.

${ }^{61}$ P. Kehr, Cómo y cuándo se hizo Aragón feudatario de la Santa Sede, Zaragoza, 1945, pp. 285-326; A.I. Lapeña Paúl, "Iglesia y moncato en el reinado de Sancho Ramírez", Sancho Ramírez, rey de Aragón, y su tiempo. 1064-1094, Huesca, 1994, pp. 131-134. Erdmann claims that Sancho Ramírez's establishment of a feudal relationship with the Holy See "may have been influenced by political motives, particularly the desire to secure the independence of his rule against claims of stronger neighbors:" C. ERDMANN, The Origin of the Idea of Crusade, Princeton, 1977, pp. 216-217.

62 D.J. Buesa Conde, Sancho Ramírez, Rey de Aragoneses y Pamploneses (1064-1084), Zaragoza, 1996, p. 91 . 
I would not want to suggest that Jaca cathedral looks, or would have looked, in all its details, like old Saint Peter's, but neither is that particularly significant. We know the significant associative value of specific constructive forms or details of medieval structures from studies by Richard Krautheimer, and certainly the tradition of looking to Saint Peter's was a venerable one during the Middle Ages. ${ }^{63}$ The Carolingian example of Fulda ${ }^{64}$ is only one instance, though an obvious one. And, in the Iberian Peninsula, the eleventh century church of Santa Maria in Ripoll, built under Abbot Oliba, friend of the Pope, was directly modeled on St. Peter's. ${ }^{65}$ When Bishop Diego Gelmírez returned to Compostela from Rome in 1099, he donated a ciborium and confessio to the sanctuary of Santiago as well as a paradisus, an atrium with a fountain that extended across its north facade, according to Serafín Moralejo explicit references to Saint Peter's in Rome. ${ }^{66}$ The crypt of the cathedral of Vic, dedicated to Sant Pere, was referred to as a confessio, i.e., employing the same name used for that architectural form in Saint Peter's in Rome. Thus, the idea that Jaca's designers would have looked to Early Christian Rome and Saint Peter's seems plausible in context of eleventh-century practice in Spain. One wonders if the use of bulls-eye windows at Jaca cathedral (fig. 19) was also a reference to Saint Peter's, as they were at Fulda,${ }^{67}$ though, or perhaps precisely because, this feature appears in other pilgrimage-road churches, for example, at Santiago de Compostela and Saint-Sernin in Toulouse.

I believe that the association with Saint Peter's should be seen at Jaca as a projection of the royal aspirations of Sancho Ramírez, whose image of his reign was tied to the Christianization of his kingdom, expanded as a result of the Christian conquest of Moslem-held territory. ${ }^{68}$ Shortly before he died in 1073, Pope Alexander II planned a crusade in Spain, which was to have been mounted under the leadership of Count Eblo II de Roucy, brother of Queen Felicia, wife of Sancho Ramírez. The Pope claimed the conquered territory to be a fiefdom of St. Peter's. And, when Gregory VII became Pope, he continued the enterprise and refers to the kingdom of Spain as from ancient time being under the jurisdiction of St. Peter, that is, Rome. ${ }^{69}$

63 R. KRAUtheimer, "Introduction to an Iconography of Medieval Architecture," Journal of the Courtauld and Warburg Institutes, V (1942), pp. 1-33; R. KRAUTHEIMER, "The Carolingian Revival of Early Christian Architecture", Art Bulletin, XXIV (1942), pp. 1-38.

${ }^{64}$ K.J. Conant, Carolingian and Romanesque Architecture 800-1200, $2^{\text {nd }}$ edition, Harmondsworth, 1966, p. 55.

65 Ibid., p. 116.

66 S. Moralejo, "On the Road: The Camino de Santiago", in The Art of Medieval Spain, A.D. 500-1200, New York, 1993, p. 182.

${ }^{67}$ K.J. Conant, Carolingian and Romanesque Architecture 800-1200, $2^{\text {nd }}$ edition, Harmondsworth, 1966, p. 55.

${ }^{68}$ D.J. Buesa Conde, "Reconquista y Cruzada en el reinado de Sancho Ramírez", Sancho Ramírez, rey de Aragón, y su tiempo. 1064-1094, Huesca, 1994, pp. 47-63.

69 P. Kehr, "El papado y los reinos de Navarra y Aragón hasta mediados del siglo XII", Estudios de Edad 


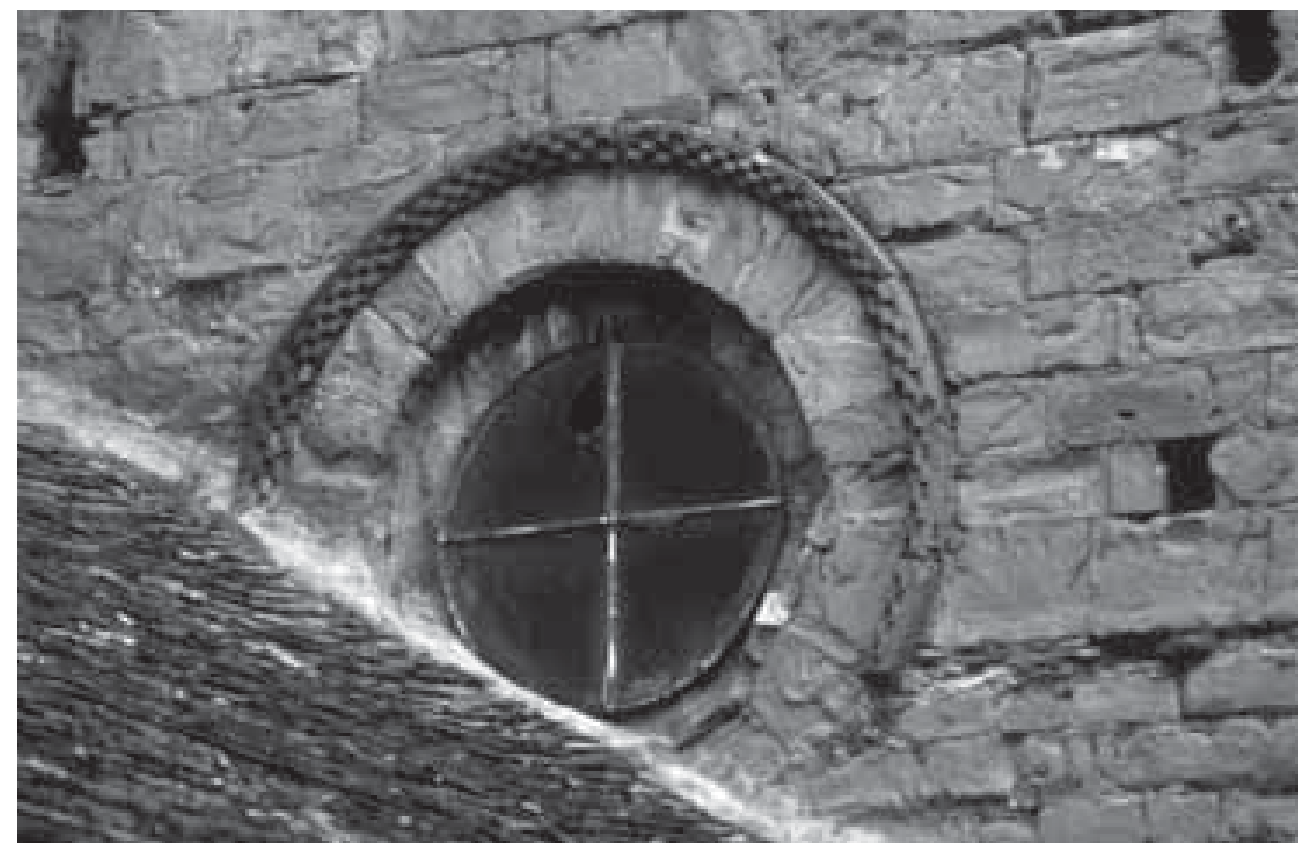

Fig. 19. Jaca cathedral, bull-eye window. Foto: D. L. Simon, Jr.

It is, in truth, hard to imagine what contemporary viewers might have thought of the large and noble stone building covered with a timber roof. But, then again, this architectural form was not the only unusual feature of the cathedral. The tympanum, so beautifully composed and elegantly placed, was, as I have mentioned, certainly among the first tympana in Europe. And, the meaning and placement of the Jaca tympanum, as I and others have tried to demonstrate, seem certainly to have been tied to the identity (or self-identity) of the newly established Aragonese king and kingdom, bishop and bishopric. Thus, it would not be surprising to find that similar concerns to those expressed on the tympanum might well have affected the choice of the architectural forms employed for the design of the building, including its wooden roof.

There has been a tendency to view the preoccupations of Aragón, a kingdom without compelling historical claims to either Visigothic or Asturian precedence, as apart from those of the other frontier kingdoms of Iberia, including Castile and Leon, perhaps reflecting the fact that Aragon was founded by Ramiro I, whose legitimacy to rule was questionable. John Williams has demonstrated that Leon, itself

Media de la Corona de Aragón, II (1946), p. 98; D. J. Buesa Conde, "Reconquista y Cruzada en el reinado de Sancho Ramírez", Sancho Ramírez, rey de Aragón, y su tiempo. 1064-1094, Huesca, 1994, p. 56; D. J. BuESA Conde. Sancho Ramírez, Rey de Aragoneses y Pamploneses (1064-1084), Zaragoza, 1996, pp. 97; 103-105. 
established as a royal capital only in the second half of the eleventh century, pressed its imperial claim by virtue of the acquisition of the venerable relics of San Isidoro and by building within a peninsular constructive tradition, based on Asturian precedents, and then only later seeking trans-Pyrenean models. ${ }^{70}$ It is significant that Aragon, faced in the 1080's with the threat of Alfonso VI of Castile's expansionist challenge to annex Zaragoza, which later monarchs also attempted, looked beyond the Pyrenees for its architectural models, to France and to Rome, reflecting perhaps the historical situation of Jaca, not having an antique tradition of its own on which it could base its claim to imperial or metropolitan status.

70 J.W. Williams, "León: The Iconography of the Capital", in Cultures of Power: Lordship, Status, and Process in Twelfth-Century Europe, Philadelphia, 1995, pp. 231-258. 